\title{
Lgl1 Is Suppressed in Oxygen Toxicity Animal Models of Bronchopulmonary Dysplasia and Normalizes During Recovery in Air
}

\author{
KATIA NADEAU, ROBERT P. JANKOV, A. KEITH TANSWELL, NEIL B. SWEEZEY, AND FEIGE KAPLAN
}

Montreal Children's Hospital Research Institute [K.N., F.K.], Departments of Paediatrics [F.K.] and Human Genetics [K.N., F.K.], McGill University, Montreal, Quebec, Canada H3A1B1; Department of Newborn and Developmental Paediatrics [R.P.J.], Sunnybrook and

Women's College Health Sciences Centre, Toronto, Ontario, Canada, M5S1B2; Department of Paediatrics [R.P.J., A.K.T., N.B.S.], Hospital for Sick Children Research Institute [A.K.T., N.B.S.], University of Toronto, Toronto, Ontario, Canada M5G1X8; Department of Physiology [A.K.T., N.B.S.], University of Toronto, Toronto, Ontario, Canada M5S1A8

\begin{abstract}
Bronchopulmonary dysplasia (BPD), a major cause of morbidity in premature infants, is characterized by arrest of lung growth and inhibited alveologenesis. We had earlier cloned lategestation lung 1 (LGL1), a glucocorticoid (GC)-induced, developmentally regulated gene in lung mesenchyme, and showed that reduced levels of late-gestation lung 1 protein ( $\lg 11)$ inhibit lung branching. Maximal fetal expression of LGL1 is concordant with the onset of alveolar septation, suggesting an additional role for lgl1 in alveologenesis. At postnatal d 7, during the period of maximal septation in postnatal rat lung, lgl1 concentrates at the tips of budding secondary alveolar septa. We studied two models of impaired postnatal alveologenesis generated by exposure of newborn rats to $60 \%$ $\mathrm{O}_{2}$ for 2 wk or $95 \% \mathrm{O}_{2}$ for 1 wk. A profound decrease of $1 \mathrm{gl1}$ expression with oxygen exposure was observed in both animal models. Animals exposed to $95 \% \mathrm{O}_{2}$ for 1 wk recovered in air over a 3-wk period, associated with normalization of lgl1 levels. Changes in lung levels of $\alpha$-actin (a marker of myofibroblast differentiation associated with alveologenesis) and the mesenchymal marker vimentin were significant but less marked. Our findings support a role for lgl1 in postnatal lung development. We speculate that deficiency of lgl1 contributes to the arrested alveolar partitioning observed in BPD and that recovery is associated with normalization of lgl1 levels.
\end{abstract} (Pediatr Res 59: 389-395, 2006)

$\mathrm{C}$ hronic lung disease of prematurity (BPD) affects $30 \%$ of newborns with birth weights $<1 \mathrm{~kg}(1)$. Recently, BPD has been associated with abnormal development of alveoli and conducting airways, secondary to premature birth, supplemental $\mathrm{O}_{2}$ and/or mechanical ventilation $(2,3)$. GCs have been used to treat or prevent BPD (4). While systemic administration of GC can improve lung mechanics in the short term, the early beneficial effects of postnatal GC are outweighed by an increased risk of short- and long-term adverse effects, including premature cessation of secondary septal formation, impaired growth, and neurodevelopmental delay $(5,6)$. Therefore, the routine use of GC for prevention or treatment of BPD

Received June 30, 2005; accepted October 10, 2005.

Correspondence: Feige Kaplan, Ph.D., McGill University-Montreal Children's Hospital Research Institute, 4060 Ste-Catherine West, Room 236, Montreal, Quebec, Canada H3Z 2Z3; e-mail: feige.kaplan@mcgill.ca.

Supported by grants from the Canadian Institutes for Health Research to Feige Kaplan and Neil B. Sweezey and by a Montreal Children's Hospital Research Institute Scholarship to Katia Nadeau.

DOI: 10.1203/01.pdr.0000198819.81785.f1 is no longer recommended (4). An improved understanding of downstream targets of GC that regulate fetal lung maturation is an essential prerequisite to the now compelling need for the establishment of safe and effective therapies for BPD.

We cloned LGL1, a GC and developmentally regulated gene encoding a secreted glycoprotein (lg11) that is, in the lung, expressed predominantly in mesenchyme $(7,8)$. LGL1 was also detected in the fetal heart, intestine, kidney, liver, and spleen (7). We demonstrated antisense LGL1 inhibition of airway branching in rat lung explant culture (9), suggesting that $\lg 11$ stimulates airway branching morphogenesis. Maximal fetal GC-responsive LGL1 expression, however, occurs at gestational d 20-21 in the rat, when branching of conducting airways is complete (7). At this time, mesenchymal lgl1 concentrates in the smooth muscle $\alpha$-actin-positive myofibroblasts, located adjacent to the epithelium, that regulate the formation of new alveolar units (9). Moreover, beginning in late canalicular lung, secreted lgl1 is associated with distal lung epithelial cells in vitro (8). We therefore hypothesized that lgl1 would have a distinct functional role during alveologenesis and that reduced lgl1 levels at this time might be associated with the impaired alveolar growth observed in BPD. We therefore elected to investigate lgl1 expression in oxygen toxicity models of neonatal lung injury that demonstrate pathologic characteristics associated with BPD.

Exposure of neonatal rats to $\geq 95 \% \mathrm{O}_{2}$ for $1 \mathrm{wk}$, a widely used model of neonatal lung injury, results in arrested lung growth without the dysplastic lesions observed in chronic human neonatal lung injury (10). Recovery of these animals in room air, following $95 \% \mathrm{O}_{2}$ exposure, is essentially complete by 4 wk $(10,11)$. By contrast, animals exposed to $60 \% \mathrm{O}_{2}$ for $14 \mathrm{~d}$, like infants with BPD, show a marked heterogeneity of response to injury in different lung regions (12). However,

Abbreviations: BPD, bronchopulmonary dysplasia; GC, glucocorticoid; LGL1, late-gestation lung 1 gene and mRNA; Igl1, late-gestation lung protein 1 
recovery of these animals is hard to assess in the short term. We therefore chose to evaluate the impact of hyperoxia on $\lg 11$ in both animal models.

\section{METHODS}

In Vivo Interventions. Procedures involving animals were according to criteria established by the Canadian Council for Animal Care and approved by Animal Care Committees at Toronto Western Hospital, University Health Network, and the McGill University Health Centre. Timed pregnant SpragueDawley rats were obtained from Taconic (Germantown, NY). Experiments were conducted as paired exposures with one chamber receiving 60\% (four litters) or $95 \% \mathrm{O}_{2}$ (four litters) and the other receiving air. Procedures for $\mathrm{O}_{2}$ exposure were as described $(11,13)$.

Immunohistochemistry. Perfused lung tissue sections (four animals per group) were inflation fixed and prepared for immunohistochemistry using the avidin-biotin-peroxidase technique as described (13). A rabbit polyclonal lgl1 antibody was raised against two synthetic lgl1 peptides (9) by Medicorp (Montreal, QC, Canada). The antibody identifies the expected protein band at $52 \mathrm{kD}$. Confirmation of the $\lg 1$ target was previously demonstrated by preabsorption of the antibody with 5-fold excess of each peptide, which eliminated lgl1 staining (9). The primary antiserum was diluted 1:100 for anti-rat lg11 antibody and 1:200 for mouse $\alpha$-actin (Neomarkers) and antivimentin antibodies (Sigma Chemical Co.) and left overnight at room temperature for all except vimentin, which was kept at $4^{\circ} \mathrm{C}$. Antibody specificity was verified by omitting the primary antibody. Biotinylated anti-mouse (Vector Laboratories) or anti-rabbit (Sigma Chemical Co.) IgG secondary antibodies (1:300) were added at room temperature for $2 \mathrm{~h}$. After immunostaining, digital images were taken using a Spot camera (Diagnostic). Northern Eclipse image analysis software (Empix Imaging Inc.) was used for semiquantification of antibody staining according to supplier. For each section at magnification $\times 400(n=4)$, two different thresholds were analyzed: a high threshold to obtain the value of the total surface area of lung tissue without air space and a lower threshold to obtain pixel counts of immunoreaction product. The relative amount of protein is expressed as the integrated immunostaining intensity over a given tissue area. For alveolar tips, eight tip regions were compared with 10 nearby nontip regions.

Isolation of Total Lung RNA. Lungs of entire litters were flash frozen in liquid nitrogen, homogenized in $4 \mathrm{~mol} / \mathrm{L}$ guanidinium thiocyanate, and extracted in phenol/chloroform extraction according to Chomczynski and Sacchi (14). RNA was resuspended in RNASecure (Ambion).

Northern blot analysis. Thirty micrograms of total lung RNA of rats exposed to $60 \% \mathrm{O}_{2}$ (four litters) or air (four litters) was hybridized to a 1.4-kb LGL1 probe generated by polymerase chain reaction (PCR) using the forward primer 5'TCAGAGTTCCGCGCAGAACG3' and the reverse primer 5' CACCAAAAGCCACGGAGGCC. An 18S biotinylated probe was used to control for loading. Similar exposures of blots were used for densitometric analysis. All samples were within the linear range for densitometry. Hybridization signals were quantified using the Fuji Image Gauge V3 program.

Quantitative real-time reverse transcriptase (RT)-PCR. Quantitative realtime RT-PCR was performed on the Mx4000 QPCR system from Stratagene (Stratagene, La Jolla, CA) using the Quantitect One-Step Probe RT-PCR Kit
(Qiagen). Gene-specific primers and FAM-labeled probes for rat cDNA sequences of LGL1, smooth muscle $\alpha$-actin and vimentin were designed using Qiagen's online QuantiProbe Design Software (Table 1). Quantitect Gene Expression Assay for mouse 18S (Qiagen) was used to normalize for the input of RNA. The results were analyzed according to the standard curve method (15). One-step real-time RT-PCR reactions were performed in $25-\mu \mathrm{L}$ volume for 45 cycles, using $10 \mathrm{ng}$ of total RNA for LGL1 and smooth muscle $\alpha$-actin, $50 \mathrm{ng}$ for vimentin, and $50 \mathrm{pg}$ for $18 \mathrm{~S}$. PCR conditions are as directed by the manufacturer. Individual runs were performed in triplicates (four litters, all groups).

Statistical analysis. All data are presented as mean \pm SEM. Statistical significance was determined by two-way analysis of variance. Pairwise group comparisons were assessed using the Student-Neuman-Keuls test.

\section{RESULTS}

Lgll localization in postnatal lung. In the rat, alveolar septation occurs in the first $2 \mathrm{wk}$ of life and is $\sim 70 \%$ complete by postnatal d $7(16,17)$. Immunolocalization of lgl1 at postnatal $\mathrm{d} 7$ and 14 (Fig. $1 A-C$ ) showed a diffuse distribution of lgl1 protein in the mesenchyme, in alveolar cells, and in the epithelia of larger conducting airways. Lgl1 levels increased until d 14 and then declined. At postnatal d 7, the lgl1 protein was concentrated at the tips of septating alveoli (Fig. 2A-C).

Lgl1 protein and mRNA levels are reduced in $60 \% \mathrm{O}_{2}$ toxicity models of BPD. Chronic lung injury in the neonatal rat exposed to $60 \% \mathrm{O}_{2}$ for $14 \mathrm{~d}$ is characterized by an overall inhibition of lung growth and DNA synthesis (13) and inhibition of myofibroblast differentiation (12) interspersed with distinct areas of parenchymal thickening with active DNA synthesis (13). We assessed lgl1 protein levels in this BPD model at postnatal $\mathrm{d} 7$ and 14 by immunohistochemistry. A dramatic reduction in lgl1 protein was observed in the lungs of rats exposed to $60 \% \mathrm{O}_{2}$ when compared with air-exposed controls (Fig. 3A, B, E). Diminished lg11 levels in 60\% $\mathrm{O}_{2}$ exposed animals remained pronounced at postnatal d 14 when the extent of lung injury most closely resembled the human BPD phenotype (Fig. $3 C-E$ ).

Northern analysis confirmed that effects of hyperoxia on lgl1 protein were accompanied by a profound reduction in LGL1 mRNA expression. LGL1 mRNA levels increased from postnatal $\mathrm{d} 7$ to $\mathrm{d} 14$ in animals exposed to air (Fig. 4A). LGL1 mRNA concentrations were decreased following 7, 10, and $14 \mathrm{~d}$ of exposure of animals to $60 \% \mathrm{O}_{2}$, when compared with

Table 1. Gene-specific primers for real-time RT-PCR

\begin{tabular}{clll}
\hline Gene & Accession no. & \multicolumn{1}{c}{ Primer } & Probe \\
\hline LGL1 & NM_138518 & Forward: CATCTACGCTGACACTTC & ATCTGTAAGGCGGCTG \\
\multirow{2}{*}{$\alpha$-Actin } & X06801 & Reverse: ATCACATCTGCATAGCCACCAA & TGCTTCCTCTTCTTCCC \\
\multirow{2}{*}{ Vimentin } & NM031140 & Forward: TGTCGCTCTGGACTTTA & \multirow{2}{*}{ CCTGGAGTCACTTCCT } \\
& & Forward: CCTGAACCTGAGAGCAGAACTA & \\
\hline
\end{tabular}
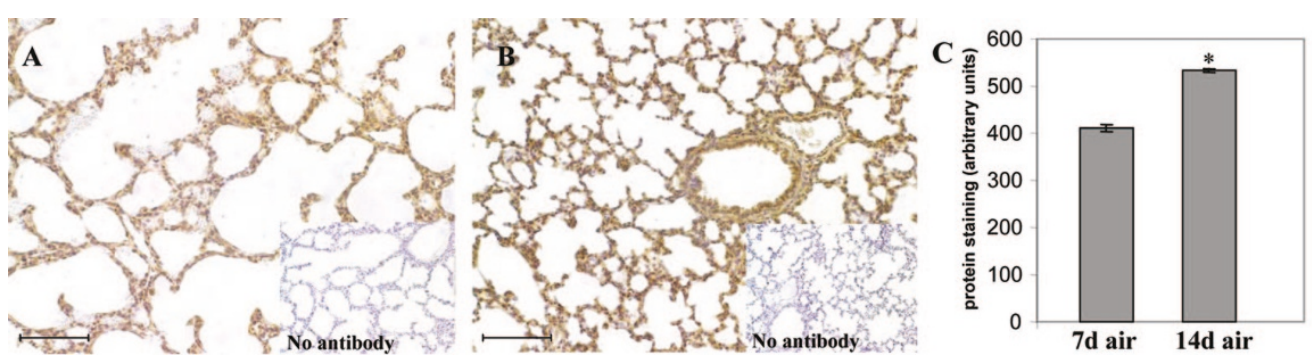

Figure 1. Immunolocalization of rat lung $\lg 11$ protein at postnatal $\mathrm{d} 7(A)$ and $14(B)(n=4)$. Insets: Control without lgl1 primary antibody. Bar $=$ $50 \mu \mathrm{m}$. (C) Semiquantification of immunoreactive lgl1 protein. $* p \leq 0.001$ for $\mathrm{O}_{2} v s$ air. 

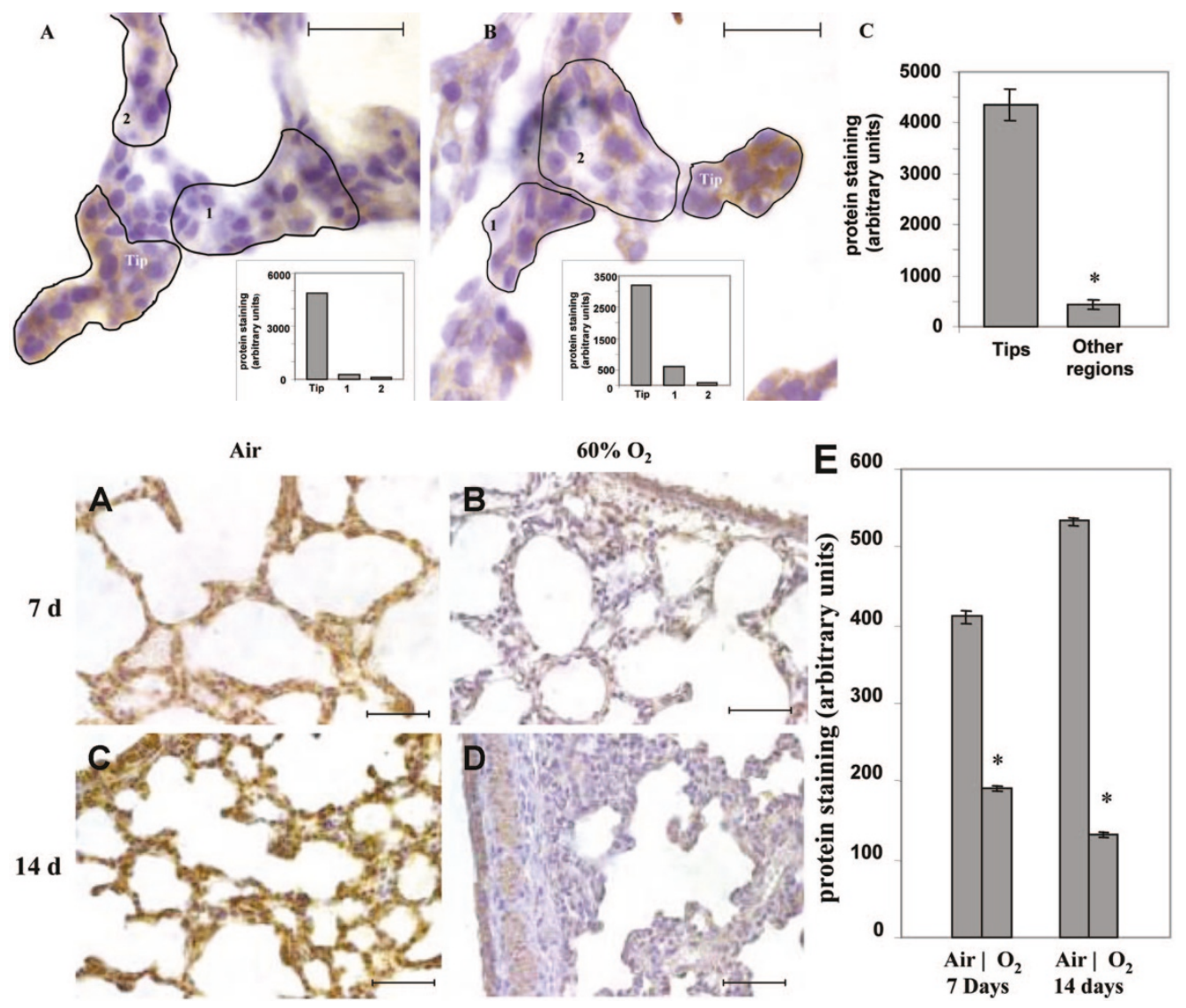

Figure 3. Lgl1 protein levels in animals exposed to $60 \% \mathrm{O}_{2}$. $\mathrm{Lgl1}$ protein levels in lungs of animals exposed to normal air for $7 \mathrm{~d}(A), 60 \% \mathrm{O}_{2}$ for $7 \mathrm{~d}$ (B), $14 \mathrm{~d}$ of normal air $(C), 60 \% \mathrm{O}_{2}$ for $14 \mathrm{~d}(D)(n=4)$. (E) Semiquantification of immunoreactive lgl1 protein. $* p$ $\leq 0.001$ for $\mathrm{O}_{2} v s$ air. $\mathrm{Bar}=50 \mu \mathrm{m}$. those of control litters exposed to room air. LGL1 mRNA levels in $60 \% \mathrm{O}_{2}$-exposed animals ranged from $10 \%$ to $28 \%$ of that observed in air-exposed controls (Fig. 4A). The effects on LGL1 mRNA levels were validated by quantitative real-time RT-PCR analysis (Fig. 4B). All further mRNA analyses were carried out using quantitative real-time RT-PCR.

Smooth muscle $\alpha$-actin protein and mRNA levels are reduced in 60\% $\mathrm{O}_{2}$ toxicity models of $\mathrm{BPD}$. Lung injury in the neonatal rat exposed to $60 \% \mathrm{O}_{2}$ for $14 \mathrm{~d}$ is associated with inhibition of myofibroblast differentiation (13). We therefore sought to establish whether levels of smooth muscle $\alpha$-actin (believed to modulate tissue remodeling in terminal lung development) would be affected by $\mathrm{O}_{2}$ exposure. In airexposed control animals, $\alpha$-actin protein concentrated at the tips of budding septa at postnatal d 7 (Fig. 5A) and levels decreased with maturation and mesenchymal thinning (Fig. 5A and $C$ ). Animals exposed to $60 \% \mathrm{O}_{2}$ for 1 wk had significantly reduced $\alpha$-actin levels when compared with air-exposed controls (Fig. 5A, $B, E$ ). Reduction in $\alpha$-actin protein was still significant at $14 \mathrm{~d}$ when $\alpha$-actin in air-exposed animals had diminished (Fig. 5C-E). The reduction in $\alpha$-actin protein in $60 \% \mathrm{O}_{2}$-exposed lungs was accompanied by a significant reduction in $\alpha$-actin mRNA (Fig. $4 C$ ).

Vimentin protein and $m R N A$ levels are reduced in $60 \%$ $\mathrm{O}_{2}$ toxicity models of BPD. In the rat, interstitial fibroblasts undergo a period of rapid proliferation from postnatal $\mathrm{d} 4$ to 13 (18). Following this period of rapid alveologenesis is a period of marked mesenchymal loss as alveolar walls become thinner. As a marker of mesenchymal cells, we assessed levels of vimentin in $60 \% \mathrm{O}_{2}$-exposed animals. Vimentin levels were
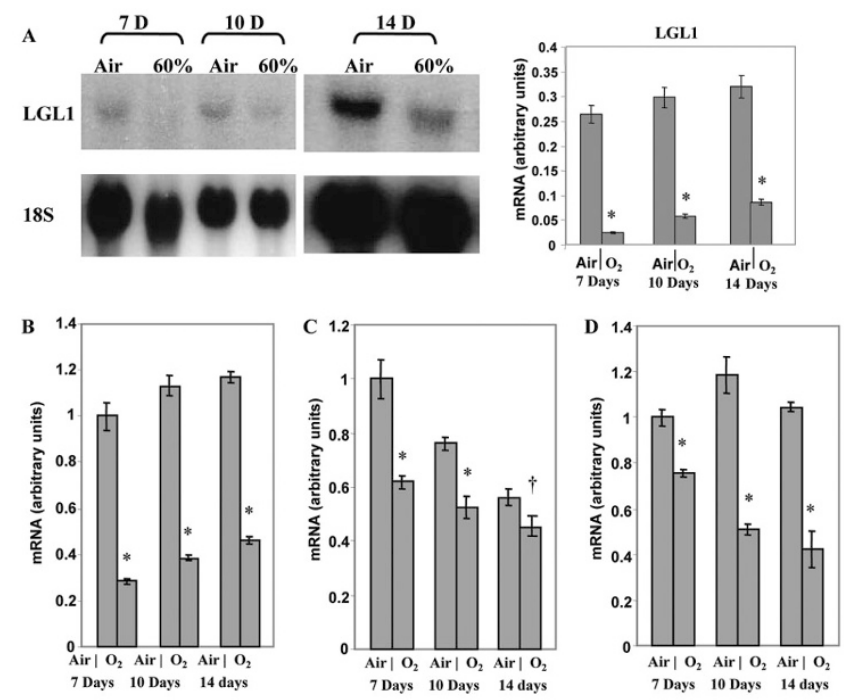

Figure 4. LGL1, $\alpha$-actin, and vimentin mRNA levels in rats exposed to $60 \%$ $\mathrm{O}_{2}$. Northern blot analysis for LGL1 $(A)$. Real-time RT-PCR mRNA quantification of LGL1 $(B), \alpha$-actin $(C)$, and vimentin $(D)(n=4)$. * $p \leq 0.001$ for $\mathrm{O}_{2}$ vs air. $\dagger p \leq 0.008$ for $\mathrm{O}_{2}$ vs air.

significantly reduced in animals exposed to $60 \% \mathrm{O}_{2}$ for $1 \mathrm{wk}$ (Fig. 6A, B, E). This difference was even more pronounced following $2 \mathrm{wk}$ of exposure to $60 \% \mathrm{O}_{2}$ (Fig. $6 C-E$ ).

Changes in vimentin immunoreactivity following 1-wk exposure to $60 \% \mathrm{O}_{2}$ were accompanied by a significant reduction in vimentin mRNA (Fig. 4D). These differences were even more pronounced at postnatal d 10 and 14, in parallel to changes observed in vimentin protein expression. In air-exposed animals, vimentin mRNA levels increased from $\mathrm{d} 7$ to $\mathrm{d} 10$ and then 

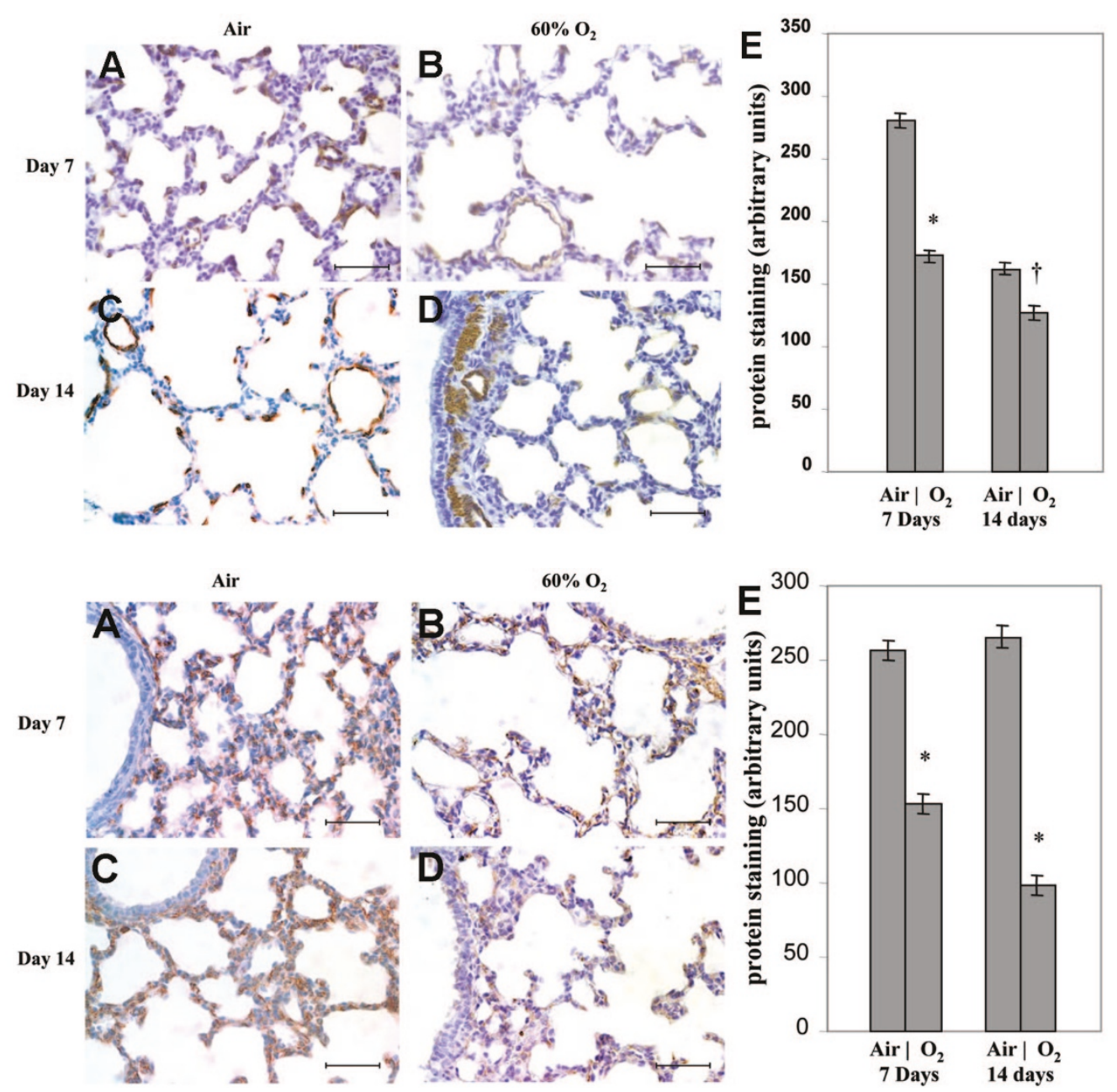

declined, consistent with the expected rapid proliferation of lung mesenchyme followed by a period of mesenchymal loss.

Lgl1 protein levels are reduced in rats exposed to $95 \% \mathrm{O}_{2}$ but normalize following recovery in air. Newborn rats exposed to $95 \% \mathrm{O}_{2}$ for $1 \mathrm{wk}$ exhibit a complete arrest of lung growth (10). No regions of residual growth, such as those observed following exposure to $60 \% \mathrm{O}_{2}$, are seen. When these animals are restored to room air, catch-up growth to normal lung structure and function is essentially complete by $4 \mathrm{wk}$ $(10,11)$. Similar to our findings in the $60 \% \mathrm{O}_{2}$-exposed rat model, lung levels of $\operatorname{lgl} 1$ in animals exposed to $95 \% \mathrm{O}_{2}$ for $1 \mathrm{wk}$ were dramatically reduced throughout the lung when compared with air-exposed controls (Figs. $7 A$ and $B$ and $8 A$ ). Following a 1-wk recovery period in room air, pups that had been exposed to $95 \% \mathrm{O}_{2}$ showed increased lgl1 immunoreactivity throughout the lung (Figs. $7 C$ and $D$ and $8 A$ ). Interestingly, a low but detectible enrichment of lgl1 was observed at the tips of many budding septa at this time (Fig. $7 D$ ). After a recovery period of 2 wk (Figs. $7 E$ and $F$ and $8 A$ ), lgl1 protein levels continued to increase and appeared to be diffusely distributed throughout the lung. Following a 3-wk recovery period in air, lgl1 levels in $95 \% \mathrm{O}_{2}$-exposed animals were generally indistinguishable from levels in air-exposed controls (Figs. $7 G$ and $H$ and $8 A$ ).

Quantitative real-time RT-PCR analysis confirmed that effects on lgl1 protein following exposure to $95 \% \mathrm{O}_{2}$ were accompanied
Figure 5. $\alpha$-Actin protein levels in animals exposed to $60 \% \mathrm{O}_{2}$. $\alpha$-Actin protein levels in lungs of animals exposed to normal air for $7 \mathrm{~d}(A), 60 \% \mathrm{O}_{2}$ for $7 \mathrm{~d}(B)$, normal air for $14 \mathrm{~d}(C), 60 \%$ $\mathrm{O}_{2}$ for $14 \mathrm{~d}(D)(n=4)$. (E) Semiquantification of immunoreactive lgl1 protein. $\mathrm{Bar}=50 \mu \mathrm{m} .{ }^{*} p \leq 0.001$ for $\mathrm{O}_{2}$ $v s$ air; $\dagger p \leq 0.008$ for $\mathrm{O}_{2} v s$ air.

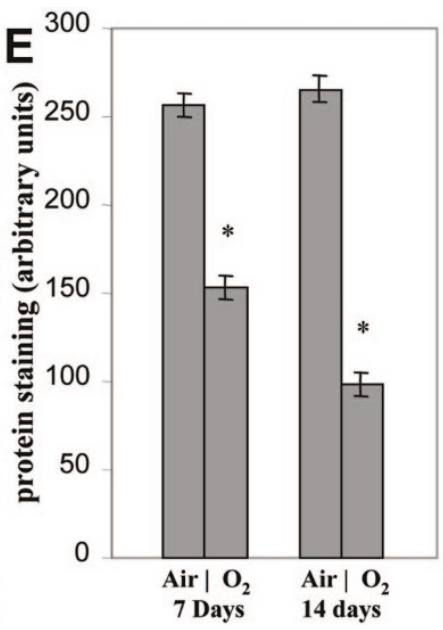

Figure 6. Vimentin protein levels in animals exposed to $60 \% \mathrm{O}_{2}$. Vimentin protein levels in lungs of animals exposed to normal air for $7 \mathrm{~d}(A), 60 \% \mathrm{O}_{2}$ for $7 \mathrm{~d}(B)$, normal air for $14 \mathrm{~d}(C)$, $60 \% \mathrm{O}_{2}$ for $14 \mathrm{~d}(D)(n=4)$. $(E)$ Semiquantification of immunoreactive lgl1 protein. $\mathrm{Bar}=50 \mu \mathrm{m} .{ }^{*} p \leq 0.001$ for $\mathrm{O}_{2} v s$ air. by a similar change in LGL1 mRNA expression (Fig. 9A). LGL1 mRNA was decreased by $60 \%$ following a 1-wk exposure to $95 \% \mathrm{O}_{2}$, when compared with control litters exposed to room air. LGL1 mRNA levels remained significantly below normal after a 1-wk recovery period in air. Following a 2-wk recovery period in air differences detected in mRNA levels of animals exposed to $95 \% \mathrm{O}_{2}$ were no longer significantly different from those of air-exposed controls.

$\alpha$-Actin and vimentin are reduced in $95 \% \mathrm{O}_{2}$ toxicity models of BPD. We also assessed changes in levels of $\alpha$-actin and vimentin in animals recovering from exposure to $95 \% \mathrm{O}_{2}$ (Figs. 8B, 9B, 10, and 11). An apparent reduction in alveolar $\alpha$-actin expressing myofibroblasts was observed in airexposed animals with maturation and mesenchymal thinning (compare parts $C, E$, and $F$ in Figure 10). Animals exposed to $95 \% \mathrm{O}_{2}$ for $1 \mathrm{wk}$ displayed a significant reduction in $\alpha$-actin levels when compared with air-exposed controls (Figs. $8 B$ and Fig. $10 A$ and $B$ ). Following a 1 -wk recovery period in air, $\alpha$-actin immunoreactivity remained significantly below normal but was more clearly defined at the tips of septating alveoli (Fig. 10D). There were no significant differences in $\alpha$-actin immunoreactivity following a 2- to 3-wk recovery period in air (Figs. $8 B$ and Fig. $10 E-H$ ).

Similarly, a significant decrease in $\alpha$-actin mRNA was detected by quantitative real-time RT-PCR following exposure to $95 \% \mathrm{O}_{2}$ for $1 \mathrm{wk}$ (Fig. $9 \mathrm{~B}$ ). Following a 2-wk recovery 


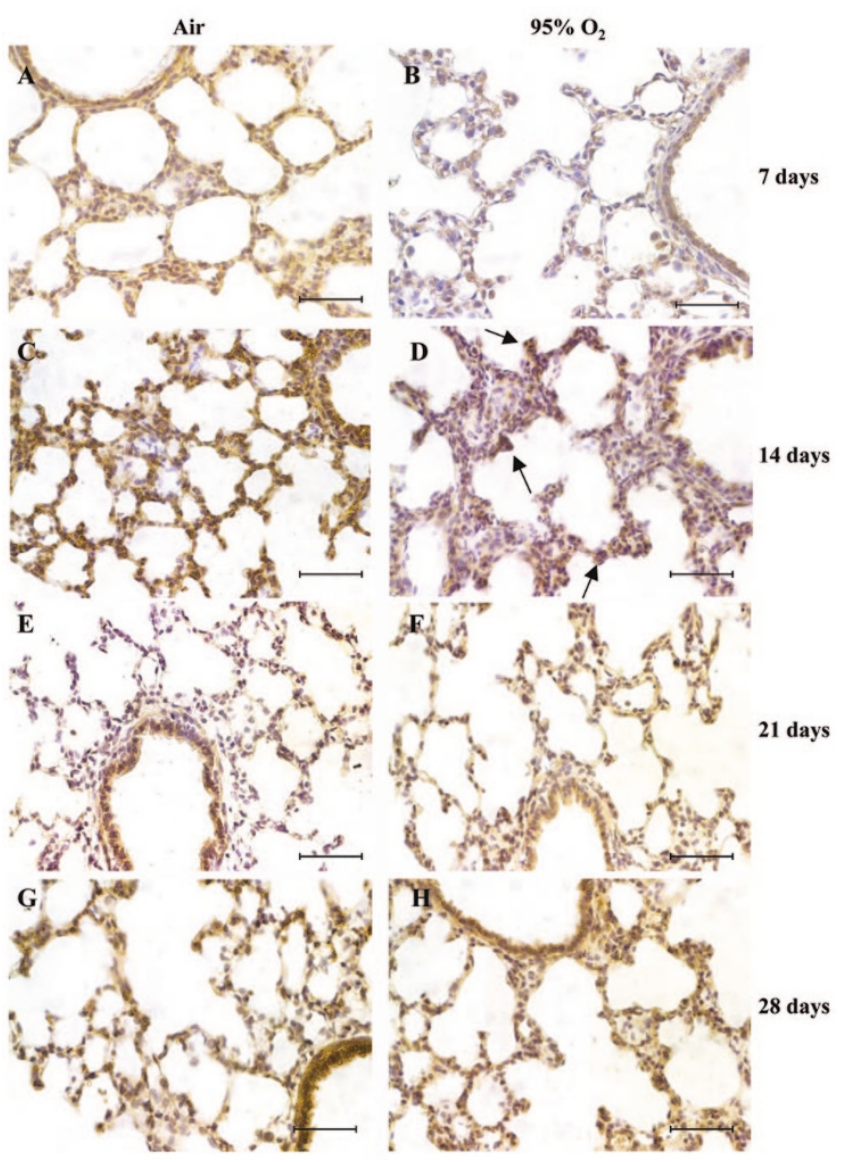

Figure 7. $\mathrm{Lgl1}$ protein levels in animals exposed to $95 \% \mathrm{O}_{2}$ for one week and allowed to recover in air. Lgl1 protein levels in lungs of animals exposed to normal air, $7 \mathrm{~d}(A) 95 \% \mathrm{O}_{2}, 7 \mathrm{~d}(B)$ normal air, $14 \mathrm{~d}(C) 95 \% \mathrm{O}_{2}, 7 \mathrm{~d}$; normal air, $7 \mathrm{~d}(D$, at this time, lgl1 can be clearly seen in septating tips, see arrows) normal air, $21 \mathrm{~d}(E) 95 \% \mathrm{O}_{2}, 7$; normal air, $14 \mathrm{~d}(F)$ normal air, $28 \mathrm{~d}(G) 95 \%$ $\mathrm{O}_{2}, 7 \mathrm{~d}$; normal air, $21 \mathrm{~d}(H),(n=4)$. Bar $=50 \mu \mathrm{m}$.

period in air, differences in $\alpha$-actin mRNA expression between $95 \% \mathrm{O}_{2}$-exposed animals and air-exposed controls were no longer significant.

Air-exposed control animals exhibited a reduction in immunoreactive vimentin associated with maturation and mesenchymal thinning [Figs. $8 C$ and 11 (compare $A$ and $C$ with $E$ and $G$ )]. Vimentin levels were reduced in animals exposed to 95\% $\mathrm{O}_{2}$ when compared with air-exposed controls (Fig. $11 A-F$ ). A gradual increase in vimentin to normal levels was observed during the 3-wk recovery period in air. At age $4 \mathrm{wk}$, vimentin levels in animals exposed to air or $95 \% \mathrm{O}_{2}$ were indistinguishable. Changes in vimentin immunoreactivity following exposure to $95 \% \mathrm{O}_{2}$ for $1 \mathrm{wk}$ were accompanied by a significant reduction in vimentin mRNA as assessed by quantitative real-time RT-PCR (Fig. 9C), which persisted for 2 wk during recovery in air.

\section{DISCUSSION}

The first 2 wk of postnatal life represent the period of maximal lung septation in the rat. Our detection of high levels of lgl1 protein during this period, and particularly its localization to growing epithelia, is consistent with the hypothesis that lgl1 has a distinct functional role in alveologenesis. Our observation that $\lg 11$ concentrates at the distal tips of septating buds at postnatal $\mathrm{d} 7$ suggests a role for lgl1 in septal growth and alveolar proliferation. Concordant with these observations, we have recently found that neonatal LGL1 mice, in which transgenic LGL1 expression is driven in the lung by a mesenchyme-specific versican promoter, display precocious alveolar septation and mesenchymal thinning (19).

The hyperoxic rat models demonstrate the major feature of modern BPD, namely, arrested/delayed alveolar growth, and therefore can be used to study the role of factors that may regulate this process. We found a profound suppression of lgl1 expression following both a 2-wk exposure to $60 \% \mathrm{O}_{2}$ and a 1-wk exposure to $95 \% \mathrm{O}_{2}$, indicating that impaired alveologenesis is associated with deficiency of lgl1. Both $\mathrm{O}_{2}$ exposure protocols are associated with a reduction in lung cell DNA synthesis $(11,13)$. The impact of hyperoxia on alveolar formation is concentration dependent. As previously assessed by measurement of mean linear intercept for animals used in this study, alveolar formation was arrested by a 1-wk exposure to $95 \% \mathrm{O}_{2}(11)$. In the $60 \% \mathrm{O}_{2}$ exposure model, the mean linear intercept, though not statistically significantly different from that observed in air-exposed animals, showed a significant increase in variance, consistent with the observed heterogeneous effect on alveolar formation (20).

Suppression of $\lg 11$ protein and LGL1 mRNA levels in animals exposed to $95 \% \mathrm{O}_{2}$ for $1 \mathrm{wk}$ was followed by a gradual increase to normal levels during a 3 -wk recovery period in air, consistent with a requirement for lgl1 for normal postnatal lung growth, alveologenesis, and repair. Normalization of lgl1 levels was concordant with the reported rapid
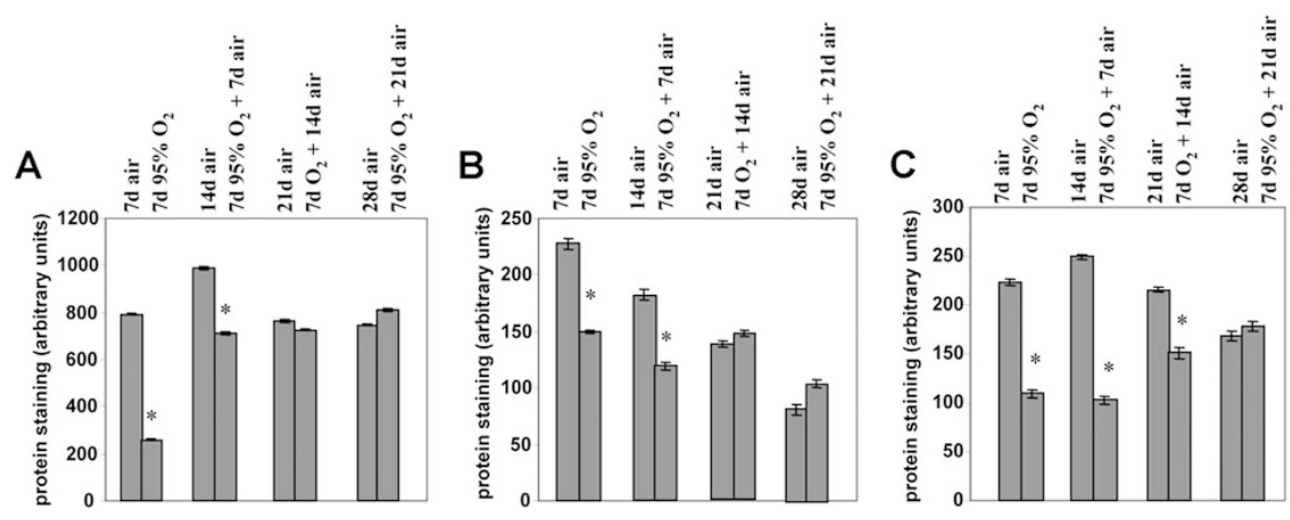

Figure 8. Semiquantification of immunoreactive $\lg 11$ protein $(A), \alpha$-actin $(B)$, and vimentin $(C)$ in animals exposed to $95 \% \mathrm{O}_{2}$ for $1 \mathrm{wk}$ and allowed to recover in air. $* p \leq 0.001$ for $\mathrm{O}_{2} v s$ air. 

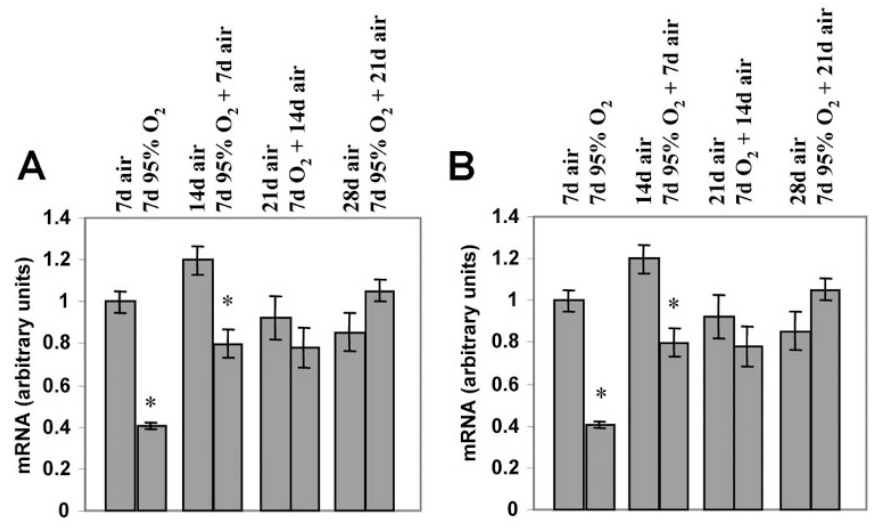

catch up in alveolar formation during recovery, as assessed by measurement of mean linear intercept (11).

$\alpha$-Actin protein and mRNA levels were also affected in both animal models of $\mathrm{O}_{2}$ toxicity. Changes in the levels of $\alpha$-actin in recovering lung of $95 \% \mathrm{O}_{2}$-exposed animals are of interest. Perinatal rat lung myofibroblasts localize to alveolar septa (21). Mitchell et al. (22) demonstrated an abundance of individual cells staining for smooth muscle $\alpha$-actin in the saccular interstitium during secondary septal formation, suggesting that $\alpha$-actin expressing myofibroblasts may be an important component in tissue remodeling during lung development. Moreover, conditions for lung remodeling after injury may also depend on reactivation of $\alpha$-actin expression. We suggest that lg11, like $\alpha$-actin, may be required for tissue remodeling and alveolar formation during postnatal lung development and following lung injury.

Both immunoreactive vimentin and vimentin mRNA levels were reduced in animals exposed to hyperoxia, with a gradual recovery to normal after recovery in air. The findings of diminished vimentin in the face of delayed thinning of the mesenchyme suggest that $\mathrm{O}_{2}$ toxicity may result in changes in the protein composition of mesenchymal tissue.

Lung injury in animals exposed to $60 \% \mathrm{O}_{2}$ for $14 \mathrm{~d}$ is typified by an overall reduction in lung growth, with patchy areas of DNA synthesis and parenchymal thickening characterized by an increase in type II epithelial cells. Enrichment of type II cells in regions of hypercellularity may reflect altered expression of growth agonists or antagonists essential to the transition of type II to type I cells associated with normal alveologenesis. Limited information is available regarding mesenchymal factors that stimulate type II to type I transition. We have shown that (1) maximal LGL1 expression in late gestation at the onset of alveolar septation is in $\alpha$-actin expressing myofibroblasts, which are believed to stimulate alveologenesis (9); (2) in late gestation and throughout the postnatal period, lgl1 protein is associated with lung epithelium (8); (3) neonatal LGL1 transgenic mice exhibit precocious alveolar septation and mesenchymal thinning (19); and, in preliminary studies, (4) the LGL1 $5^{\prime}$ proximal promoter includes binding sites for both GC and retinoic acid receptors, important modulators of late gestation and postnatal lung development. It is thus tempting to speculate that lgl1, regulated by GC and/or retinoic acid and secreted by fibroblasts, may be one factor involved in the transition of epithelial type

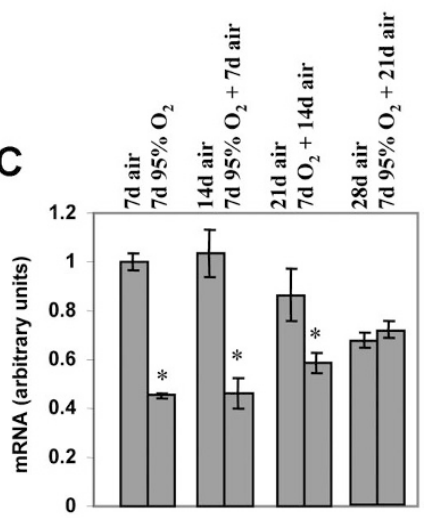

Figure 9. mRNA quantification of LGL1 $(A), \alpha$-actin $(B)$, and vimentin $(C)$ by real-time RT-PCR in animals exposed to $95 \% \mathrm{O}_{2}$ for $1 \mathrm{wk}$ and allowed to recover in air. $* p \leq 0.001$ for $\mathrm{O}_{2}$ vs air.
II to type I cells and that deficient lg11 may contribute to the epithelial hypercellularity and disrupted alveolarization observed in $\mathrm{O}_{2}$ toxicity models of BPD. Suitable experiments using in vitro and in vivo animal models will be necessary to evaluate this hypothesis. Moreover, whether the reduction in lgl1 observed in these animal models is a direct consequence of increased $\mathrm{O}_{2}$ levels on fibroblasts, secondary to effects of hyperoxia on other lung cell types, or the result of other neurohumoral effects known to aggravate hyperoxia-induced

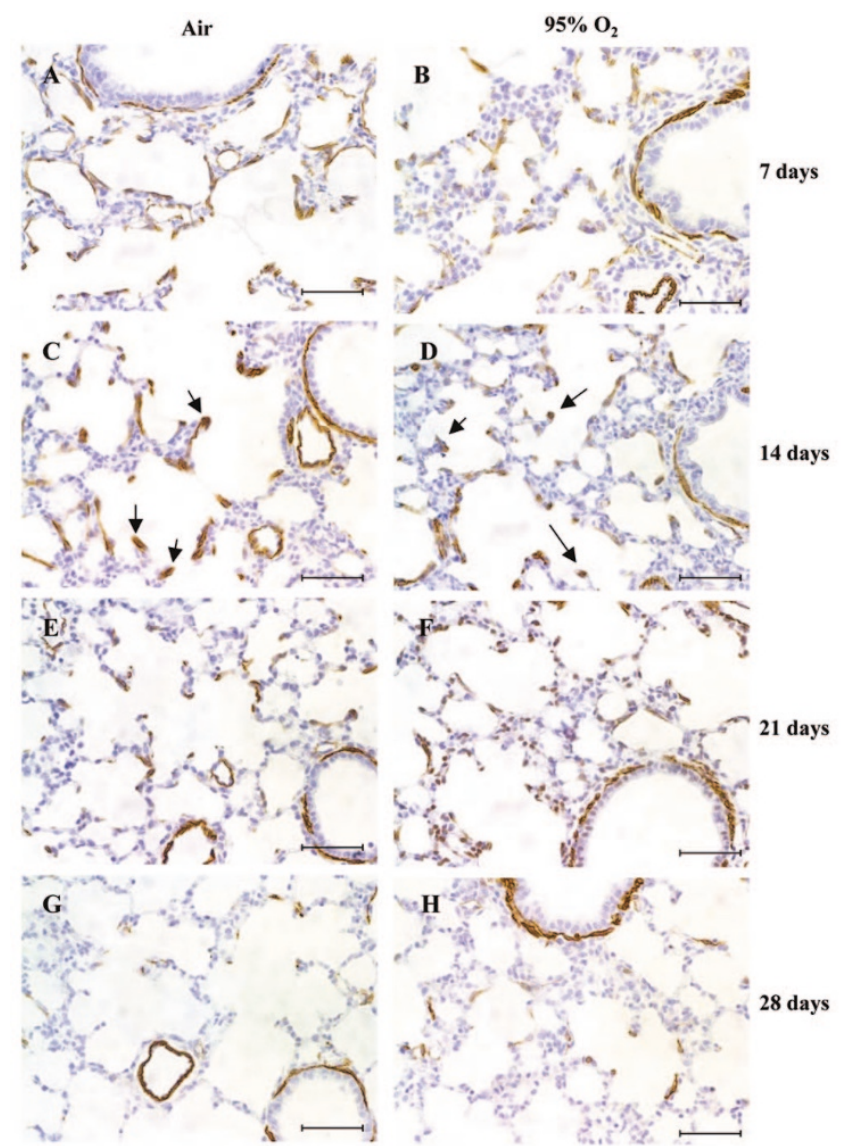

Figure 10. $\alpha$-Actin protein levels in animals exposed to $95 \% \mathrm{O}_{2}$ for one week and allowed to recover in air. $\alpha$-Actin protein levels in lungs of animals exposed to normal air, $7 \mathrm{~d}(A) 95 \% \mathrm{O}_{2}, 7 \mathrm{~d}(B)$ normal air, $14 \mathrm{~d}(C) 95 \% \mathrm{O}_{2}$, $7 \mathrm{~d}$; normal air, $7 \mathrm{~d}(D$, at this time $\alpha$-actin can be clearly seen in septating tips [C,D, arrows]) normal air, $21 \mathrm{~d}(E) 95 \% \mathrm{O}_{2}, 7 \mathrm{~d}$; normal air, $14 \mathrm{~d}(F)$ normal air, $28 \mathrm{~d}(G) 95 \% \mathrm{O}_{2}, 7 \mathrm{~d}$; normal air, $21 \mathrm{~d}(H),(n=4)$. Bar $=50 \mu \mathrm{m}$. 


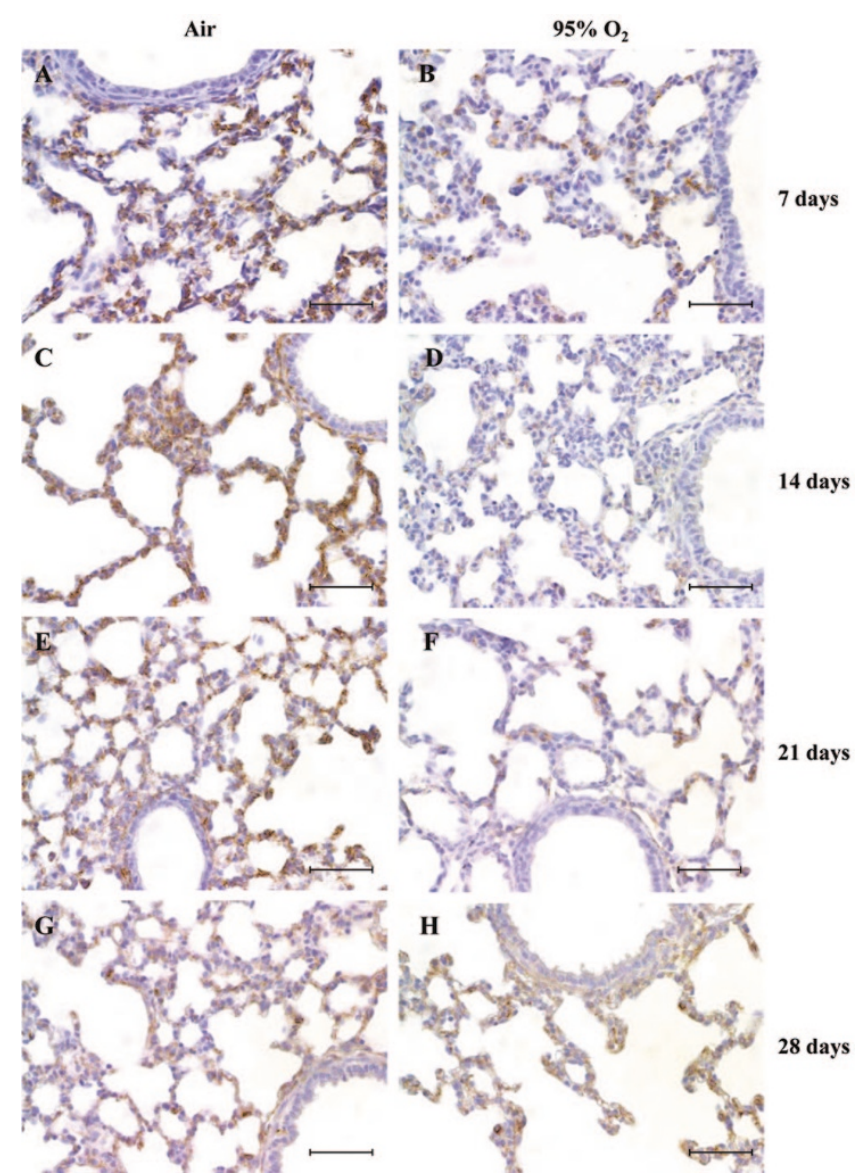

Figure 11. Vimentin protein levels in animals exposed to $95 \% \mathrm{O}_{2}$ for one week and allowed to recover in air. Vimentin protein levels in lungs of animals exposed to normal air, $7 \mathrm{~d}(A) 95 \% \mathrm{O}_{2}, 7 \mathrm{~d}(B)$ normal air, $14 \mathrm{~d}(C) 95 \% \mathrm{O}_{2}, 7 \mathrm{~d}$; normal air, $7 \mathrm{~d}(D)$ normal air, $21 \mathrm{~d}(E) 95 \% \mathrm{O}_{2}, 7 \mathrm{~d}$; normal air, $14 \mathrm{~d}(F)$ normal air, $28 \mathrm{~d}$ (G) $95 \% \mathrm{O}_{2}, 7 \mathrm{~d}$; normal air, $21 \mathrm{~d}(H),(n=4)$. Bar $=50 \mu \mathrm{m}$.

lung injury [e.g. elevated bombesin-like peptides (23), circulating GC levels (24)] remains to be determined.

Many key mediators of lung morphogenesis are expressed throughout fetal development and into postnatal life, suggesting that they may be critical for both airway branching (early) and alveologenesis (late). Examples include fibroblast growth factors (25), transforming growth factor $\beta$ (26,27), BMP4 (28), and platelet-derived growth factor $\alpha(29,30)$. Our observations suggest that LGL1 may be a new member of this group of multifunctional developmental regulators of lung organogenesis (29).

The routine use of GC for prevention or treatment of BPD is no longer recommended due to the potential long-term adverse effects on lung growth and neurodevelopment (2-4). There is therefore a compelling need to identify more specific downstream targets of GC that may provide the beneficial effects of $\mathrm{GC}$ on lung mechanics in the context of BPD without incurring the attendant GC toxicity. Our present findings support a role for lgl1 in alveologenesis and suggest that deficiency of lgl1 may contribute to the arrested alveolar partitioning observed in BPD. As such, lgl1 may have relevance to the development of future strategies for prophylaxis and treatment of BPD.

\section{REFERENCES}

1. Lee SK, McMillan DD, Ohlsson A, Pendray M, Synnes A, Whyte R, Chien LY, Sale J 2000 Variations in practice and outcomes in the Canadian NICU network: 1996-1997. Pediatrics 106:1070-1079

2. Jobe AJ 1999 The new BPD: an arrest of lung development. Pediatr Res 46:641-643

3. Bourbon J, Boucherat O, Chailley-Heu B, Delacourt C 2005 Control mechanisms of lung alveolar development and their disorders in bronchopulmonary dysplasia. Pediatr Res 57:38R-46R

4. Committee on Fetus and Newborn 2002 Postnatal corticosteroids to treat or prevent chronic lung disease in preterm infants. Pediatrics 109:330-338

5. Jobe AH 2003 Antenatal factors and the development of bronchopulmonary dysplasia. Semin Neonatol 8:9-17

6. Grier DG, Halliday HL 2003 Corticosteroids in the prevention and management of bronchopulmonary dysplasia. Semin Neonatol 8:83-91

7. Kaplan F, Ledoux P, Kassamali FQ, Gagnon S, Post M, Koehler D, Deimling J, Sweezey NB 1999 A novel developmentally regulated gene in lung mesenchyme: homology to a tumor-derived trypsin inhibitor. Am J Physiol Lung Cell Mol Physiol 276:L1027-L1036

8. Oyewumi L, Kaplan F, Sweezey NB 2003 Lgl1, a mesenchymal modulator of early lung branching morphogenesis, is a secreted glycoprotein imported by late gestation lung epithelial cells. Biochem J 376:61-69

9. Oyewumi L, Kaplan F, Gagnon S, Sweezey NB 2003 Antisense oligodeoxynucleotides decrease LGL1 mRNA and protein levels and inhibit branching morphogenesis in fetal rat lung. Am J Respir Cell Mol Biol 28:232-240

10. Randell SH, Mercer RR, Young SL 1990 Neonatal hyperoxia alters the pulmonary alveolar and capillary structure of 40-day-old rats. Am J Pathol 136:1259-1266

11. Jankov RP, Luo X, Campbell A, Belcastro R, Cabacungan J, Johnstone L, Frndova H, Lye SJ, Tanswell AK 2003 Fibroblast growth factor receptor-1 and neonatal compensatory lung growth after exposure to 95\% oxygen. Am J Respir Crit Care Med 167:1554-1561

12. Buch S, Han RN, Cabacungan J, Wang J, Yuan S, Belcastro R, Deimling J, Jankov R, Lye SJ, Post M, Tanswell AK 2000 Changes in expression of platelet-derived growth factor and its receptors in the lungs of newborn rats exposed to air or $60 \%$ $\mathrm{O}(2)$. Pediatr Res 48:423-433

13. Han RN, Buch S, Tseu I, Young J, Christie NA, Frndova H, Lye SJ, Post M, Tanswell AK 1996 Changes in structure, mechanics, and insulin-like growth factorrelated gene expression in the lungs of newborn rats exposed to air or $60 \%$ oxygen. Pediatr Res 39:921-929

14. Chomczynski P, Sacchi N 1987 Single-step method of RNA isolation by acidguanidinium-thiocyanate-phenol-chloroform extraction. Anal Biochem 162:156-159

15. Bustin SA 2002 Quantification of mRNA using real-time reverse transcription PCR (RT-PCR): trends and problems. J Mol Endocrinol 29:23-29

16. Massaro D, Massaro GD 2002 Invited Review: pulmonary alveoli: formation, the "call for oxygen", and other regulators. Am J Physiol Lung Cell Mol Physiol 282:L345-L358

17. Burri PH 1974 The postnatal growth of the rat lung. 3. Morphology. Anat Rec 180:77-98

18. Bruce MC, Honaker CE, Cross RJ 1999 Lung fibroblasts undergo apoptosis following alveolarization. Am J Respir Cell Mol Biol 20:228-236

19. Oyewumi L, Gagnon S, Kaplan F, Sweezey NB 2004 Transgenic LGL1 mice display advanced lung maturation. Am J Hum Genet 75:206a

20. Yi M, Jankov RP, Belcastro R, Humes D, Copland I, Shek S, Sweezey NB, Post M, Albertine KH, Auten RL, Tanswell AK 2004 Opposing effects of $60 \%$ oxygen and neutrophil influx on alveologenesis in the neonatal rat. Am J Respir Crit Care Med 170:1188-1196

21. Lindahl P, Karlsson L, Hellstrom M, Gebre-Medhin S, Willetts K, Heath JK, Betsholtz C 1997 Alveogenesis failure in PDGF-A-deficient mice is coupled to lack of distal spreading of alveolar smooth muscle cell progenitors during lung development. Development 124:3943-3953

22. Mitchell JJ, Reynolds SE, Leslie KO, Low RB, Woodcock-Mitchell J 1990 Smooth muscle cell markers in developing rat lung. Am J Respir Cell Mol Biol 3:515-523

23. Subramaniam M, Sugiyama K, Coy DH, Kong Y, Miller YE, Weller PF, Wada K, Wada E, Sunday ME 2003 Bombesin-like peptides and mast cell responses: relevance to bronchopulmonary dysplasia? Am J Respir Crit Care Med 168:601-611

24. Barazzone-Argiroffo C, Pagano A, Juge C, Metrailler I, Rochat A, Vesin C, Donati Y 2003 Glucocorticoids aggravate hyperoxia-induced lung injury through decreased nuclear factor-kappa B activity. Am J Physiol Lung Cell Mol Physiol 284:L197-L204

25. Hokuto I, Perl AT, Whitsett JA 2003 Prenatal, but not postnatal, inhibition of fibroblast growth factor receptor signaling causes emphysema. J Biol Chem 278:415-421

26. Lecart C, Cayabyab R, Buckley S, Morrison J, Kwong KY, Warburton D, Ramanathan R, Jones CA, Minoo P 2000 Bioactive transforming growth factor-beta in the lungs of extremely low birthweight neonates predicts the need for home oxygen supplementation. Biol Neonate 77:217-223

27. Zhou L, Dey CR, Wert SE, Whitsett JA 1996 Arrested lung morphogenesis in transgenic mice bearing an SP-C-TGF-beta 1 chimeric gene. Dev Biol 175:227-238

28. Weaver M, Dunn NR, Hogan BL 2000 Bmp4 and Fgf10 play opposing roles during lung bud morphogenesis. Development 127:2695-2704

29. Demayo F, Minoo P, Plopper CG, Schuger L, Shannon J, Torday JS 2002 Mesenchymal-epithelial interactions in lung development and repair: are modeling and remodeling the same process? Am J Physiol Lung Cell Mol Physiol 283:L510-L517

30. Warburton D, Tefft D, Mailleux A, Bellusci S, Thiery JP, Zhao J, Buckley S, Shi W, Driscoll B 2001 Do lung remodeling, repair, and regeneration recapitulate respiratory ontogeny? Am J Respir Crit Care Med 164:S59-S62 